удК 338.512:658.5

\title{
УПРАВЛІННЯ ВИТРАТАМИ НА ПІДПРИЕМСТВАХ В УМОВАХ РИЗИКУ
}

\section{COST MANAGEMENT AT ENTERPRISES IN CONDITIONS OF RISK}

\author{
Костецька Наталія Іванівна \\ кандидат економічних наук, доцент, \\ Західноукраїнський національний університет \\ ORCID: https://orcid.org/0000-0002-7122-5800
}

\author{
Kostetska Nataliia \\ West Ukrainian National University
}

\begin{abstract}
Стаття присвячена актуальним питанням управління витратами на сучасних підприємствах у нестабільних умовах розвитку економічних відносин. 3'ясовано значення управління витратами із урахування впливу чинників ризику. Розглянуто фрункції менеджменту в контексті управління витратами. Виділено планування, організацію, мотивацію та контроль як основні функції управління діяльністю підприємства загалом і витратами зокрема. Наведено основні класифікаційні ознаки й види витрат, які насамперед потрібно брати до уваги при виконані наведених функцій управління, а також розглянуто пов'язані із ними можливі ризики для подальшої діяльності підприємства. Встановлено, що такий підхід до управління витратами дасть змогу забезпечити дослідження джерел і причин виникнення ризиків, попередити їхній негативний вплив на величину та структуру витрат.
\end{abstract}

Ключові слова: витрати, управління витратами, планування, організація, мотивація, контроль, ризики.

Статья посвящена актуальным вопросам управления издержками на современных предприятиях в нестабильных условиях развития экономических отношений. Выяснено значение управления издержками с учетом влияния фракторов риска. Рассмотрены фрункции менеджмента в контексте управления издержками. Выделены планирование, организация, мотивация и контроль как главные функции управления деятельностью предприятия в целом и издержками в частности. Приведены основные классификационные признаки и виды издержек, которые, прежде всего, нужно принимать во внимание при выполнении приведенных функций управления, а также рассмотрены связанные с ними возможные риски для дальнейшей деятельности предприятия. Установлено, что такой подход к управлению издержками позволит обеспечить исследование источников и причин возникновения рисков, предотвратить их негативное влияние на величину и структуру издержек.

Ключевые слова: издержки, управление издержками, планирование, организация, мотивация, контроль, риски.

The article is devoted to topical issues of cost management at modern enterprises in unstable conditions of economic relations. The theoretical and methodological bases of the research are scientific works of researchers on the cost management taking into account the uncertainty and unpredictability of the enterprise environment. General scientific methods of research were used in the article such as theoretical generalization, analysis and synthesis, abstract and logical methods. The importance of cost management taking into account the impact of risk factors is clarified. Management functions in the context of cost management are considered. Planning, organizing, motivating and controlling are highlighted as the main functions of enterprise management in general and cost management in particular. The main classification features and types of costs that should be taken into account when performing cost management functions, as well as the possible risks associated with the future enterprise activity are showed. The importance of planning production costs in conditions of uncertainty is described. It is emphasised on the need to identify potential risks during the planning process and study the extent of their impact on costs. It is noted that the organizing should ensure a combination of all components of the production and economic activities of the enterprise in space and time. Organizational risks related to mistakes made by employees of the enterprise or shortcomings of the enterprise management structure are identified. The risks associated with the motivation of the company's staff are determined. Qualitative risks relate to the needs, incentives and motives of employees, as well as quantitative risks relate to the provision of resources. Controlling that provides feedback and allows to monitor the use of resources, costs and performance of the enterprise is investigated. It is established that the lack of effective 
and comprehensive system for monitoring deviations in the implementation of management decisions can cause certain risks. It is important to make managerial decisions on costs taking into account the probability of risks that prevent the expected course of events and achieving desired results.

Keywords: costs, cost management, planning, organizing, motivating, controlling, risks.

Постановка проблеми. Невід'ємною складовою будь-якої діяльності підприємства та усіх його структурних підрозділів є витрати. Досить часто витрати виникають навіть тоді, коли не здійснюють ті чи інші дії, тобто вони є наслідком бездіяльності. Витрати є грошовим виразом спожитих у результаті виробничо-господарської діяльності ресурсів з метою створення цінності для споживачів і досягнення цілей підприємства. Проте в сучасних умовах невизначеності та непередбачуваності середовища господарювання можна спостерігати, що витрати на багатьох підприємствах незалежно від форми власності та галузевої приналежності зростають пропорційно, а інколи навіть і швидшими темпами, ніж обсяги випуску продукції, що значною мірою залежить від впливу безлічі чинників ризику. Тому попри важливість і актуальність управління витратами також потрібно враховувати імовірність виникнення ризиків різного спрямування і ступеня важкості впливу на результати діяльності підприємств.

Аналіз останніх досліджень і публікацій. Теоретичні та практичні аспекти управління витратами висвітлені у працях багатьох вітчизняних і зарубіжних вчених. Проте для ефрективного управління витратами на підприємствах необхідно брати до уваги імовірність появи тих чи інших ризиків, які можуть перешкоджати досягненню бажаних цілей. Проблеми впливу ризиків на діяльність підприємств також перебували у полі зору дослідників. Зокрема питання управління витратами з урахуванням ризиків досліджували В. О. Занора, О. І. Карінцева, Т. І. Партин, Н. Ф. Романюк, Е. А. Федорова, М. О. Харченко, А. І. Ясінська та інші науковці.

Відомо, що ринкові умови господарювання зумовлюють виникнення проблеми не стільки щодо визначення рівня витрат, їхнього розподілу за об'єктами та забезпечення мінімізації, скільки щодо управління ними в умовах ризиковості та визначення раціональності здійснення і досягнення необхідної прибутковості [1, с. 158]. У літературі розглядають механізм управління витратами промислового підприємства і ступінь ризикованості процесу управління витратами [2, с. 30]. Рішення щодо управління витратами і саме середовище, в якому вони приймаються, є джерелами ризи- ків. Ризики при управління витратами мають різну економічну природу. Вони можуть бути пов'язані із зовнішнім і внутрішнім середовищем підприємства, вибором того чи іншого управлінського рішення [3, с. 136].

Однак особливості управління витратами на підприємствах в умовах ризику є ще недостатньо досліджені та потребують подальшого вивчення із урахуванням змін, що відбуваються у суспільстві та економічному середовищі фрункціонування сучасних підприємств.

Формулювання цілей статті. Метою статті $€$ дослідження особливостей управління витратами на сучасних підприємствах в нестабільних умовах розвитку економічних відносин $з$ урахування впливу чинників ризику. Основними завданнями $є$ : розглянути срункції менеджменту в контексті управління витратами, виділити основні ознаки групування витрат, що дозволить виявити можливі ризики у діяльності підприємств.

Виклад основного матеріалу дослідження. Особливістю процесу управління витратами є його цільова спрямованість на визначення оптимального розміру витрат 3 метою підвищення ефективності діяльності підприємства. Управління витратами повинно бути орієнтовано на раціональне використання ресурсів у процесі виробничо-господарської діяльності, а також забезпечення максимально високого рівня віддачі від них.

Процес управління витратами характеризується певною послідовністю виконуваних дій, зокрема: розроблення, прийняття і реалізація рішень щодо фрормування величини і структури витрат, а також контроль за їхнім виконанням. Управління витратами $є$ важливою складовою в системі управління підприємством і має бути узгоджено із усіма іншими елементами цієї системи. Управління діяльністю підприємства передбачає наявність таких основних фрункцій як планування, організація, мотивація і контроль [4]. Тому на всіх стадіях і рівнях управління витратами необхідно дотримуватись реалізації зазначених срункцій [5, с. 48].

Планування як фрункція управління логічно передує виконанню усіх інших фрункцій. Тому планування витрат на виробництво продукції $\epsilon$ важливою первинною складовою в системі управління витратами підприємства. Метою планування витрат виробництва $€$ економічне 
обґрунтування планової величини витрат, а також розподіл витрат за видами діяльності та статтями витрат. Проте в умовах невизначеності важливо також забезпечити: виявлення потенційних ризиків і дослідження ступеня їхнього впливу на рівень витрат; врахування наслідків зміни дії організаційно-технічних і економічних чинників під впливом імовірних ризиків на розмір витрат і їхню структуру; розрахунок гранично допустимих витрат 3 урахуванням ризиків; усунення неесективних витрат. У процесі планування важливо оптимізувати витрати, що передбачає відповідність величини і структури витрат рівню розвитку підприємства та його становищу на ринку. Оптимальні витрати повинні бути зорієнтовані на забезпечення належної якості продукції, рівня обслуговування і дієвої реклами, а не лише здійснення процесу виробництва та реалізації продукції. Планування виробничих витрат має бути основане на використанні прогресивних норм, узгоджене із ресурсними і фрінансовими можливостями підприємства, а темп приросту витрат повинен бути нижчий, ніж темп приросту обсягів виробництва продукції.

Роль організації у системі управління витратами полягає у забезпеченні поєднання усіх складових елементів виробничо-господарської діяльності підприємства у просторі та часі. Завдяки процесу організації розділяють місця фрормування витрат і центри відповідальності. Організаційний аспект в управлінні витратами покликаний забезпечити практичне спостереження за зміною витрат, шляхом встановлення відповідальних осіб і узгодження меж їхньої компетенції із виробничою та організаційною структурами підприємства. Однак цей процес пов'язаний із певними організаційними ризиками, що стосуються помилок, допущених працівниками підприємства, або є результатом недоліків у структурі управління підприємством.

Мотивація у системі управління витратами передбачає виявлення способів впливу на діяльність працівників підприємства 3 метою заохотити їх дотримуватися встановленого планом розміру витрат, а також виявляти нові можливості їх зниження. Для цього на підприємствах використовують економічні (підвищення заробітної плани, виплата премій, нарахування доплат тощо) та негрошові (гнучкі грасріки роботи, умови праці, просування по службі тощо) методи мотивації персоналу. Проте одночасно на підприємстві виникає ризик недосягнення максимально можливої вигоди від управління витратами за рахунок прагнення до завищення планових витрат і недобросовісного ставлення працівників до виконання поставлених завдань. Вплив оточуючого середовища і особистісних чинників на результативність витрат, що стосуються мотивації персоналу, може спричинити ризики, пов'язані із поведінкою керівників і працівників через незадоволення їхніх потреб і очікувань відповідно до затрачених зусиль.

Контроль $є$ заключним елементом у системі управління витратами і забезпечує зворотний зв'язок шляхом порівняння планових витрат із фрактичними. Сутність контролю полягає у спостережені та нагляді за виробничо-господарськими процесами 3 метою виявлення відхилень і протидії небажаним явищам. Здійснити ґрунтовну перевірку відхилень витрат від запланованого рівня неможливо належним чином без попереднього обліку і аналізу витрат. Облік витрат дозволяє підготувати і згрупувати інсрормацію про фрактичні витрати для подальшого аналізу. Аналіз витрат необхідний для порівняння фрактичних витрат із плановими, з'ясування причин відхилень від плану, оцінювання ефективності використання ресурсів підприємства, виявлення резервів і шляхів зниження витрат. Результати аналізу витрат є інформацією для контролю та слугують підґрунтям для підготовки і прийняття управлінських рішень стосовно планування витрат на майбутній період. Проте контроль, як і інші складові системи управління витратами, пов'язаний із певними ризиками. Зокрема ризик контролю полягає у тому, що на підприємствах може бути відсутня дієва та комплексна система спостереження за відхиленнями у процесі реалізації прийнятих управлінських рішень.

Для ефрективної реалізації вищенаведених фрункцій у контексті управління витратами в умовах ризику необхідно враховувати, що у процесі виробничо-господарської діяльності виникають різні витрати і, відповідно, їхній вплив на результати фрункціонування підприємства буде різним. Тому необхідно виділити ті класифікаційні ознаки та види витрат, які найбільшою мірою впливають на виконання фуннкцій управління, розглянути пов'язані із ними можливі ризики та їх значення для подальшої діяльності підприємства.

Функція планування передбачає розрахунок конкретних витрат на визначений майбутній період. Залежно від необхідності та можливості планування доцільно розділяти витрати на планові й непланові. В ринкових умовах господарювання діяльність підприєм- 
ства орієнтована на задоволення ринкового попиту і потреб споживачів, тому запланований обсяг випуску та реалізації продукції $\epsilon$ основою для визначених планових витрат. Непланові витрати попередньо не розраховують, а визначають їхню фрактичну величину та частку в структурі собівартості продукції чи сукупних витрат підприємства. Порівняння планових витрат із фрактичними дає змогу визначити розмір відхилення, спонукає до виявлення причин, що їх спричинили, і дозволяє оцінити відповідний ризик. Планування витрат здійснюють на основі норм витрачання ресурсів, тому, залежно від необхідності та можливості нормування, витрати розділяють на нормовані та ненормовані. Нормування усіх видів ресурсів дасть змогу забезпечити ефрективне управління витратами та знизити чи уникнути ризику перевитрат.

Реалізація фрункції організації у процесі управління витратами залежить від специфріки виробничого процесу і організаційної структури управління. Розподіл витрат залежно від місця виникнення чи центрів відповідальності на витрати виробництва, цеху, дільниці, технологічного переділу, служби чи відділу, залежно від ролі витрат у діяльності підприємства на виробничі, управлінські та комерційні, витрати на інноваційну діяльність, трансакційні витрати дає змогу виявляти ризик пов'язаний із використанням матеріальних, трудових і фрінансових ресурсів, а також ризик наявності «вузьких» місць у роботі конкретних структурних підрозділів і виробничо-господарській діяльності підприємства загалом.

Мотивація як фрункція управління орієнтована на підвищення ефективності роботи персоналу підприємства, тому понесені при цьому витрати пов'язані із його утриманням. Залежно від того, для яких працівників будуть застосовувати мотиваційні заходи, розрізняють різні ознаки групування витрат. Зокрема із мотивацією працівників пов'язані витрати на виплату заробітної плати, відрахування на соціальні заходи, податки і податкові платежі, витрати на страхування тощо. Тобто це обов'язкові для підприємства витрати, величина яких залежить не тільки від кадрової політики підприємства, а й вимог чинного законодавства. Мотивацію персоналу можуть здійснювати за центрами відповідальності чи місцями виникнення витрат, що передбачає відповідний розподіл витрат. Залежно від періодичності введення тих чи інших стимулів доцільно розділяти витрати на одноразові та поточні. Ступінь впливу на рівень прибутку передбачає розподіл витрат на ті, що пов'язані та непов'язані із отриманням прибутку на підприємстві. Витрати на персонал, які впливають на отримання прибутку, пов'язані із доходами від виробництва і реалізації продукції чи надання послуг, та $€$ обов'язковими для підприємства. Непов'язані із прибутками підприємства витрати стосуються соціального забезпечення працівників, благодійності та інших подібних затрат. Необхідність у таких витратах на сучасних підприємствах обумовлена розвитком соціальних тенденцій у суспільстві, що впливає на імідж підприємства, а також потребою мотивувати персонал до підвищення продуктивності праці, якості продукції та виконуваних робіт.

Оскільки мотивація стосується практично усіх сорер діяльності підприємства, то недосягнення бажаного ефекту від понесених витрат спричиняє ризик розбіжностей у очікуваннях керівництва і працівників підприємства. При мотивації персоналу можуть виникати якісні ризики, що стосуються потреб, стимулів і мотивів працівників, та кількісні ризики, пов'язані із ресурсним забезпеченням. До ресурсних відносять ризики: фрінансового забезпечення, що проявляється у відсутності фрінансових можливостей для належного мотивування; кадрового забезпечення, що полягає у неналежному ставленні керівників до вивчення мотивів і реалізації стимулів; матеріального забезпечення, що спричиняє втрати через відсутність обладнання чи програмного забезпечення для ефективної мотивації; ризик інфрормаційного забезпечення, що призводить до втрати через відсутність або недосконалість інфрормаційної бази про потреби, мотиви, стимули працівників [6].

Функція контролю в системі управління витратами пов'язана із можливістю керівників чи відповідальних осіб спостерігати за використанням ресурсів, витратами і результатами діяльності. Тому слід виділити ознаки групування витрат, важливі для реалізації цієї фрункції. Зокрема доцільно розподіляти витрати за умовами і термінами їх виникнення на нормативні, планові та фрактичні. На основі встановлених норм витрачання ресурсів і очікуваного результату розраховують нормативні витрати, які $€$ базою для планування витрат. Фактичні витрати порівнюють із плановими, що дає змогу виявляти розмір відхилення понаднормативних, непланованих та неефективних витрат. У результаті таких розрахунків можна встановити відповідні ризики та причини їх виникнення. 
Також важливо розуміти наскільки керівники тих чи інших структурних підрозділів підприємства можуть впливати на витрати. Для цього доцільно класифікувати витрати за ступенем регулювання, що дозволяє розділити їх на регульовані та нерегульовані. Регульовані витрати знаходяться у межах компетенції відповідальних осіб і залежать від їхніх прийнятих рішень, а на нерегульовані витрати неможливо впливати. Одні й ті ж витрати можуть бути нерегульовані для одного структурного підрозділу, але в іншому підрозділі їх можуть регулювати. Задля уникнення ризику понаднормативних, непланових і непродуктивних витрат необхідно чітко структурувати усі ресурси підприємства та пов'язані із ними витрати щодо можливості їхнього регулювання у різних структурних підрозділах для досягнення поставлених цілей.

Висновки. Завдяки управлінню витратами на підприємстві визначають потребу в ресурсах (обсяг ресурсів для використання в певному місці та у визначений час) і на основі цього встановлюють джерела надходження і можливості для їхнього залучення, виявляють необхідність у додаткових грошових коштах, а також забезпечують максимально високий рівень віддачі від їхнього використання. Проте у сучасних нестабільних умовах розвитку економічних відносин управління витратами на рівні підприємства необхідно здійснювати у комплексі із управлінням ризиками. Такий підхід повинен забезпечувати дослідження джерел і причин виникнення ризиків, їхній вплив на величину і структуру витрат, а також виявлення шляхів їх усунення у процесі управління витратами. При прийнятті управлінських рішень щодо витрат необхідно ураховувати імовірність виникнення ризиків, які перешкоджають очікуваному розвитку подій і досягненню бажаних результатів за умов виникнення непланових ситуацій.

Вищенаведені характеристики функцій системи управління витратами $€$ загальними та можуть стосуватися багатьох підприємств, які здійснюють свою діяльність в умовах невизначеності та ризику. Однак галузева специфріка та особливості формування витрат вносять певну своєрідність у систему управління витратами для різних виробництв в умовах ризику, що потребує відповідних подальших досліджень.

\section{СПИСОК ВИКОРИСТАНИХ ДЖЕРЕЛ:}

1. Занора В. О. Ризик-орієнтоване управління виробничо-технологічними витратами машинобудівних підприємств. Бізнес Інфрорм. 2014. № 4. С. 157-161.

2. Федорова Е. А., Романюк Н. Ф. Интегральная оценка рисков при управлении затратами промышленного предприятия. Известия ТулГУ. Экономические и юридические науки. 2012. № 1-1. С. 30-47. URL: http://cyberleninka.ru/article/n/integralnaya-otsenka-riskov-pri-upravlenii-zatratami-promyshlennogopredpriyatiya

3. Федорова Е. А., Романюк Н. Ф. Управление затратами промышленного предприятия: анализ связи группировок затрат и рисков. Известия ТулГУ. Экономические и юридические науки. 2012. № 3-1. С. 130-144. URL: https://cyberleninka.ru/article/n/upravlenie-zatratami-promyshlennogo-predpriyatiya-analiz-svyazi-gruppirovokzatrat-i-riskov

4. Мескон М., Альберт М., Хедоури Ф. Основы менеджмента / пер. с англ. Л. И. Евенко. Москва : Дело ЛТД, 1994. 702 c.

5. Kostetska N. I., Litkovets Yu. O. Risk cost management in Ukraine's fat and oil industry. Economic and social development of Ukraine in XXI century: national vision and globalization challenges : Collection of scientific articles. Oklahoma City, 2017. P. 46-48.

6. Сай Л. П., Пшик-Ковальська О. О. Ризики при мотивуванні персоналу підприємства. Ефрективна економіка : електронний журнал. 2017. № 8. URL: http://www.economy.nayka.com.ua/?op=1\&z=5718

\section{REFERENCES:}

1. Zanora, V. O. (2014) Ryzyk-oriientovane upravlinnia vyrobnycho-tekhnolohichnymy vytratamy mashynobudivnykh pidpryiemstv [Risk-oriented management of production and technological costs of engineering enterprises]. Biznes Inform, no. 4, pp. 157-161. (in Ukrainian)

2. Fedorova, E. A., Romanjuk, N. F. (2012) Integralnaia otsenka riskov pri upravlenii zatratami promyshlennogo predpriiatiia [Integral risk's estimation for expense management of industrial enterprise]. Izvestiia TulGU. Ekonomicheskie i yuridicheskie nauki, no. 1-1, pp. 30-47. Available at: http://cyberleninka.ru/article/n/integralnaya-otsenka-riskov-pri-upravlenii-zatratami-promyshlennogo-predpriyatiya (in Russian) 
3. Fedorova, E. A., Romanjuk, N. F. (2012) Upravlenie zatratami promyshlennogo predpriiatiia: analiz sviazi gruppirovok zatrat i riskov [Management of expenses of the industrial enterprise: analysis of communication of groups of expenses and risks]. Izvestiia TuIGU. Ekonomicheskie i yuridicheskie nauki, no. 3-1, pp. 130-144. Available at: https://cyberleninka.ru/article/n/upravlenie-zatratami-promyshlennogo-predpriyatiya-analiz-svyazigruppirovok-zatrat-i-riskov (in Russian)

4. Mescon, M. H., Albert, M., Khedouri, F. (1994) Osnovy menedzhmenta [Fundamentals of management], Translated by L. I. Evenko. Moscow: Delo LTD, 702 p. (in Russian)

5. Kostetska, N. I., Litkovets, Yu. O. (2017) Risk cost management in Ukraine's fat and oil industry. Economic and social development of Ukraine in XXI century: national vision and globalization challenges: Collection of scientific articles. Oklahoma City, pp. 46-48.

6. Sai, L. P., Pshyk-Kovalska, O. O. (2017) Ryzyky pry motyvuvanni personalu pidpryiemstva [Risks of staff motivation of the enterprise]. Efektyvna ekonomika: elektronnyi zhurnal, no. 8. Available at: http://www.economy.nayka.com.ua/ ?op=1\&z=5718 (in Ukrainian) 